\title{
不透過水制群を有する 流れの構造に関する実験的研究 EXPERIMENTAL STUDY ON THE STRUCTURE OF OPEN CHANNEL FLOW WITH IMPERMEABLE SPUR DIKES
}

\author{
池田駿介 ${ }^{1} \cdot$ 吉池智明 $^{2} \cdot$ 杉本高 ${ }^{2}$ \\ Syunsuke IKEDA， Tomoaki YOSHIIKE，Takashi SUGIMOTO \\ 1フェロー会員 工博 東京工業大学教授 工学部土木工学科 \\ 2 学生会員 学士 (工) 東京工業大学大学院 理工学研究科土木工学専攻 \\ （广152-8552 東京都目黒区大岡山二丁目 12-1）
}

\begin{abstract}
It is important for river engineers to know the hydraulic roles of spur dikes. A series of laboratory tests for horizontal structure of open channel flow with spur dikes was performed by varying the interval of spur dikes. The results indicate that the structure of flow is different according to the interval. The reattachment length is found to be a function of the interval of spur dikes. The momentum transport rate between the main flow region and spur dike region in the most upstream spur dike region takes a peak when the interval is 4.0 times of the length of a spur dike. The flow near the tip of the subsequent spur dike plays an important role in the momentum transport rate in the first spur dike region.
\end{abstract}

Key Words : spur dikes, horizontal structure of flow, momentum transport, mass transport, interval of spur dikes

\section{1.はじめに}

水制工は流れに対して粗度として働き，流速を減少 させ，水はねによって流れの向きを変えるという効果 によって川岸を浸食から守る目的で用いられてきた。 近年は，水制工の設置によって多様な流れを生み出せ ることから，河川環境に配慮した工法としても用いら れている.

水制群を有寸る流れは次第に流下方向一変化しない 流れとなる. これを平衡領域，そのような領域に至る までを遷移領域と呼んでいる．最近の研究としては， 固定床直線水路に単一水制を設置し，水制周りの流れ の構造を調べたもの ${ }^{1)}$ ，移動床における越流型水制周 りの洗掘，堆積に関するもの 2，3などがあるが，水制 群を有する流れの研究は, 平衡領域を扱ったものが多 く，水制群先頭の遷移領域はあまり扱われていない。 松岡 住は，実河川において水制群から放出される渦が， 水制域における底泥の堆積状況に大きく寄与している ことを指摘しており，水制先端から剥離する渦の特性
を知ることは重要な課題である，また，近年注目され ている環境面での効果を考えるとき，水制域・主流域 間での物質輸送を考えることは重要になる.

本研究では, 流れの構造を支配する因子として水制 間隔に注目し, 不透過水制群先頭における遷移領域を 中心に, 流れの基本的な構造, 剥離渦の特性, 水制域 主流域間での質量・運動量交換に注目し，実験を行っ た.

\section{2. 実験概要}

実験には図-1 のような長さ $12 \mathrm{~m}$, 幅 $1.2 \mathrm{~m}$ の循環式 可変勾配直線水路を使用し, 不透過水制として長さ $30 \mathrm{~cm}$, 高さ $30 \mathrm{~cm}$, 厚さ $1 \mathrm{~cm}$ のアクリル板を水路左岸 に設置した. 水制群先頭の左岸側位置を原点として流 下方向を $\mathrm{x}$ 軸, 横断方向を $\mathrm{y}$ 軸, 河床からの高さを $\mathrm{z}$ 軸として，座標を設定している. なお，上流側の水制， 水制区間から，それぞれ水制 1 ，水制区間 1 とし，ま た，水制区間 1 の水制域を水制域 1 と呼び，流下方向 


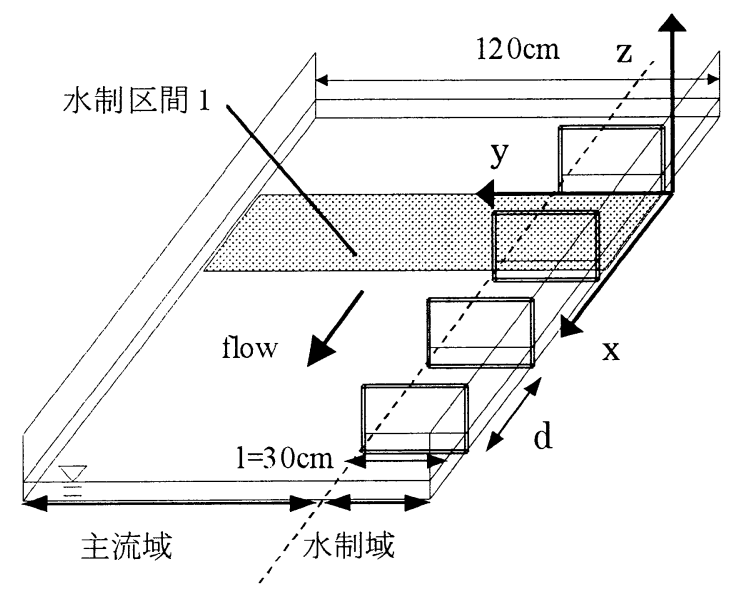

表-1 実験条件

\begin{tabular}{|c|c|c|c|c|c|c|c|c|}
\hline Case & & E1 & E2 & E3 & E4 & E5 & E6 & E7 \\
\hline 水路床勾配 & $\mathrm{i}_{\mathrm{b}}$ & $10^{-3}$ & \multicolumn{7}{|c|}{0.51} \\
\hline 流量 & $\mathrm{Q}(1 / \mathrm{s})$ & \multicolumn{6}{|c|}{10.9} \\
\hline 水制間隔/水制長 & $\mathrm{d} / 1$ & 1 & 2 & 3 & 5 & 7 & 3 & 4 \\
\hline 水制間隔 & $\mathrm{d}(\mathrm{cm})$ & 30 & 60 & 100 & 150 & 200 & 90 & 120 \\
\hline 水制数 & $\mathrm{N}_{\mathrm{SD}}$ & 15 & 10 & 7 & 6 & 5 & 7 & 6 \\
\hline
\end{tabular}

図-1 実験水路概略図

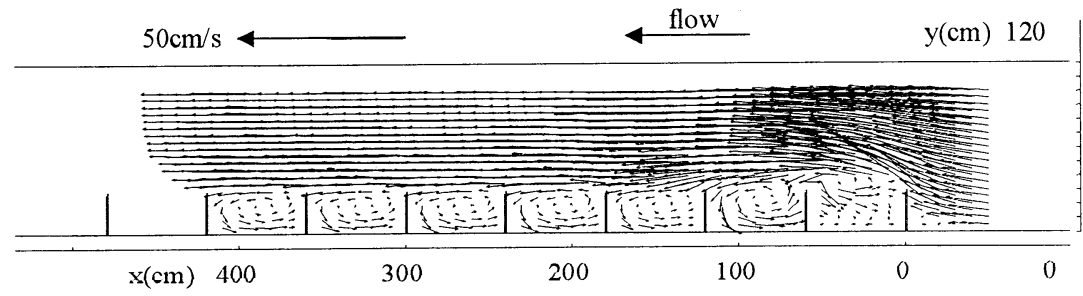

$\mathrm{y}(\mathrm{cm}) 120$

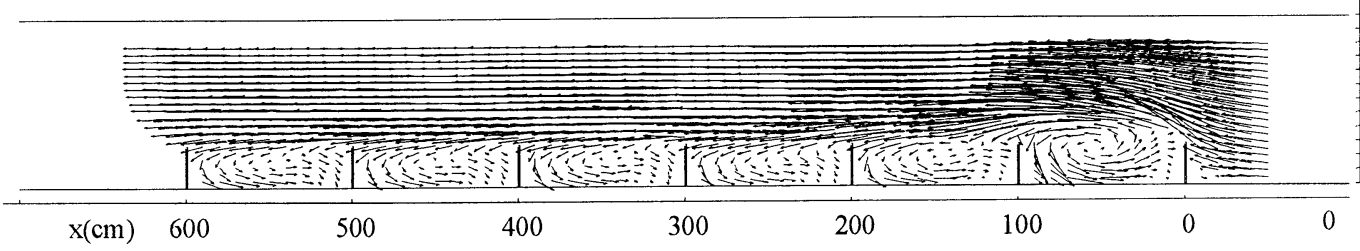

$\mathrm{y}(\mathrm{cm}) 120$

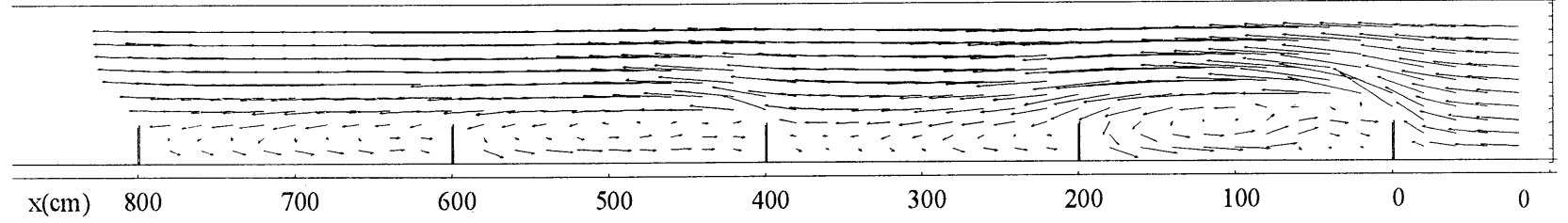

図-2 $\mathrm{z}=0.4 \mathrm{~h}$ における時間平均流速ベクトルの例

流速を u，横断方向流速を v で表す事とする．実験条 件は表-1 に示すとおりである. 水制間隔による变化 を見るため，各ケースともに水制間隔以外の水理条件 を固定している.

水路全体の平面的な構造を把握するために, 河床か ら 4 割の水深での流速を平均流速として，二成分電磁 流速計を用いて流下方向, 横断方向を同時に測定した 5)。また，容量式波高計を用いて水制から放出される 剥離渦の特性や，それによって生じる水制域内での水 面変動を測定した．水制・主流域間での物質輸送に関 係する指標として質量・運動量の交換について検討す る. そのために，水制先端を結ぶ境界面上で，二成分 レーザードップラー流速計を用いて流下方向, 横断方 向の流速を 2 次流による局所的な 3 次元性を考慮し
て水深方向に $\mathrm{z}=1,2,3,4 \mathrm{~cm} の 4$ 点で測定した (平 均水深は全ケースともに約 $5 \mathrm{~cm}$ 程度である)。ここで は, E6(d/1=3.0), E7(d/1=4.0)の 2 ケースを追加した.

\section{3. 水制群を有する流れの構造}

\section{(1)流速測定結果}

流れ場の全体的な構造を把握するため図-2に時間 平均流速ベクトルを示寸. 水制周りの流れ場は, 水制 先端からの剥離, それに伴う剥離渦の放出, 逆流域な どを持つ複雑な流れとなっていることが知られている. また，単一非越流不透過水制を有する流れにおいて， 水制先端から剥離した流れは一定距離を流下し再付着 


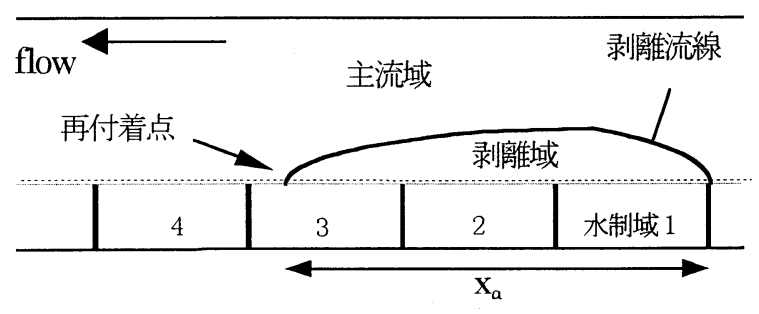

図-3 剥離域, 再付着点

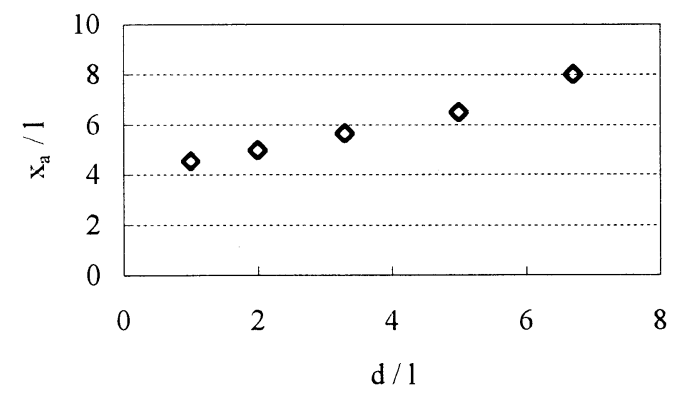

図-4 水制群先端から剥離域の 最下流地点までの距離

する. この再付着の位置は時間的に上・下流入変化し， また, 時間平均再付着点距離は水制長さの 14 倍の距 離であることが指摘されているゅ。

水制群を有する流れにおける再付着点を，剥離した 流れが水制群の先端を結んだラインに到達する位置と して定義する．また，剥離流線とこのラインとに囲ま れる領域を剥離域と呼ぶことにする（図-3）。主流域 において流下方向流速の瞬間值が負とならないことを 剥離域外である条件として，再付着点が最も下流に現 れた地点の距離 $\mathrm{x}_{\mathrm{a}}$ を求めた結果を図-4に示寸。この 結果，水制間隔が狭いほど短い距離で再付着している ことがわかる。

水制域内では反時計回りの循環流が生じている. 流 下方向の平衡域では，この循環流は規則的なパターン を繰り返すようになる．水制間隔の狭いものでは水制 域全体を一つの循環流が占めており，水制間隔が広い ものになると, 反時計回りの循環流に加え, 上流側の 水制背後に死水域的な時計回りの循環流を伴うように なる．水制間隔が狭い二つのケース(E1，E2)において は, 遷移領域である水制群先頭の水制域において, 時 計回りと反時計回りの循環流を併せ持つ流れが見られ

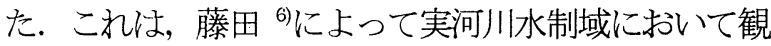
測された流れと一致している.

水制間隔の狭い 3 ケース (E1，E2，E3)で遷移領域 内の水制先端において上流側に向から逆流が見られる. さらに, 水制 2 の先端における流速に注目すると, ケ 一ス E1,E2 では横断方向流速が正負に大きく変化し, 水制域一の流入と，流出を繰り返す周期的な流れとな っている(図-5). この変動の周期は, ケース E1 で
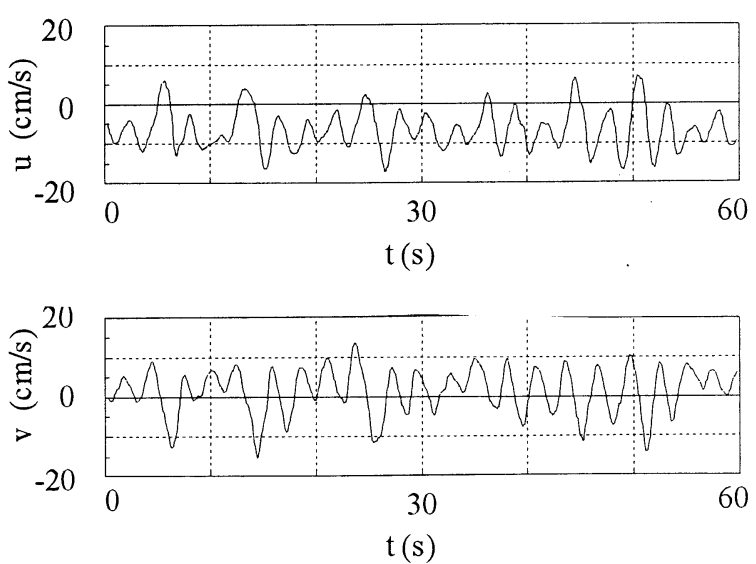

(a) E1 $(x=30 \mathrm{~cm}, y=32 \mathrm{~cm})$
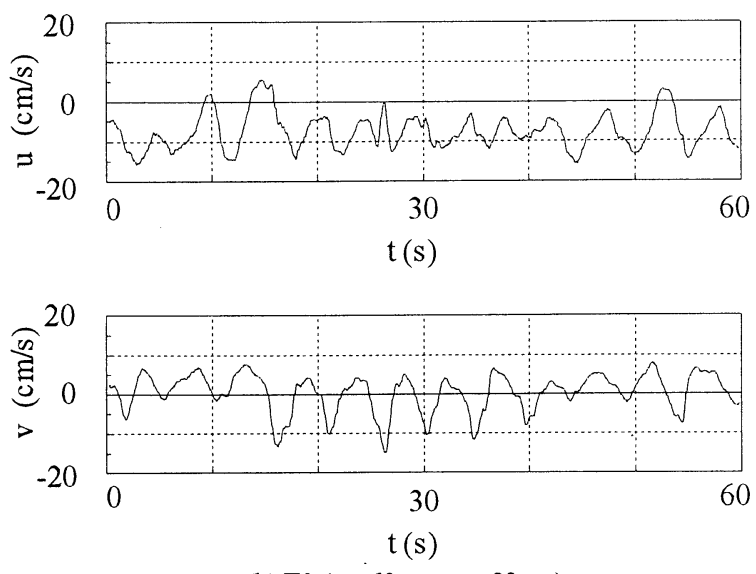

(b) $E 2(x=60 \mathrm{~cm}, y=32 \mathrm{~cm})$

図-5 水制 2 先端における流速の時間変動

2. 7 秒, E2 で 4.9 秒であった.

\section{(2) 水面変動測定結果}

\section{a) 水制域の水面変動}

ケース E1，E2 では水制域内の水面が，流下方向に 同位相で周期的に変動している様子が観察された. 水 制間隔が広いケースでは，水面変動が小さく確認でき なかった.この水面変動の周期は，ケース $\mathrm{E} 1$ で 2.9 秒，E2 で 5.0 秒であり, 先に述べた水制先端を周り 込む逆流の周期にほぼ一致している。村らわは，フ ルード数が大きい流れにおいて，開水路中の死水域で セイシュに起因する水面変動の発生を指摘している. 本実験では，この水面変動の周期は閉鎤性水域の水面 の固有振動数と一致せず，セイシュとは異なるもので ある. この水面変動は，剥離流線が周期的に再付着点 付近の水制にぶつかることによって，その水制域の水 位が上昇し, 前方の水制域との間に水位差が生じるこ とにより生じる上思われる.

\section{b) 剥離渦の特性}

ケース E3，E4，E5 で, 剥離渦の移動経路に近いと 思われる水制域先端から主流域側入 $10 \mathrm{~cm}$ 離れたライ ン上 $(\mathrm{y}=40 \mathrm{~cm})$ における水面変動の周期を調べると, 
図-6 のようになり，流下寸るに従って周期が大きく なっている. それに対して，ケース E1，E2 では $\mathrm{y}=40 \mathrm{~cm}$ のライン上での水面变動の周期がそれでれ，2.9 秒, 5.0 秒で一定であり，水制域内の水面変動の周期に等 しい. ケース $\mathrm{E} 1, \mathrm{E} 2$ の $\mathrm{x}=22 \mathrm{~cm}, \mathrm{y}=40 \mathrm{~cm}$ の地点におけ る水面変動を FFT 法によってスペクトル解析した結果 を図-7 に示寸．ケース $\mathrm{E} 2$ では路が 2.5 秒のサブビ 一クが存在している。これは，剥離渦の水面変動によ るものと考えられる。 ケース E1 では剥離渦の周期が a)で述ベたメカニズムによる水制域内の水面変動に

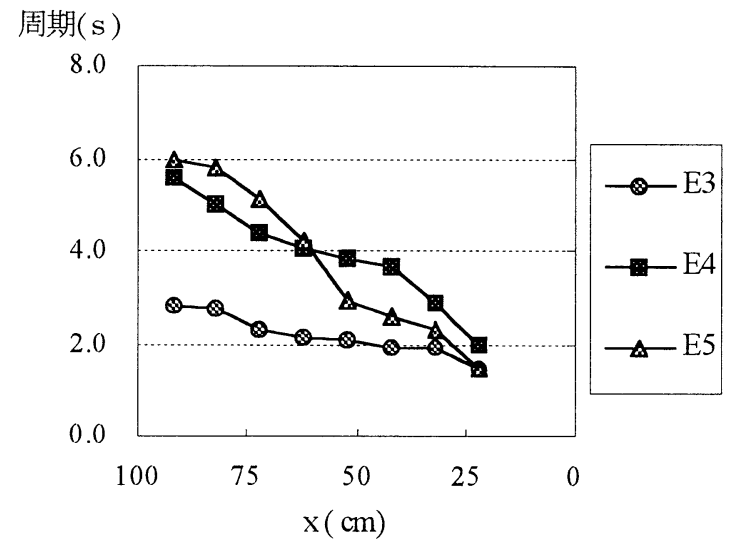

図-6＼cjkstart水面変動周期の流下方向変化

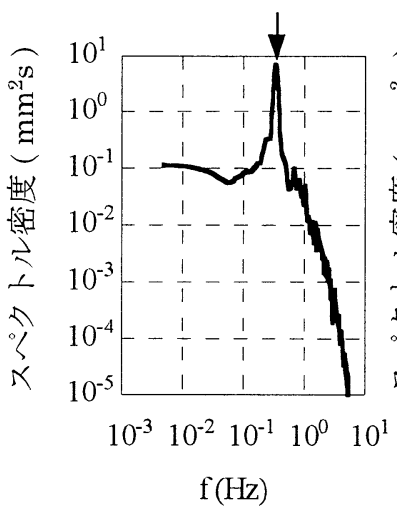

(a) E1

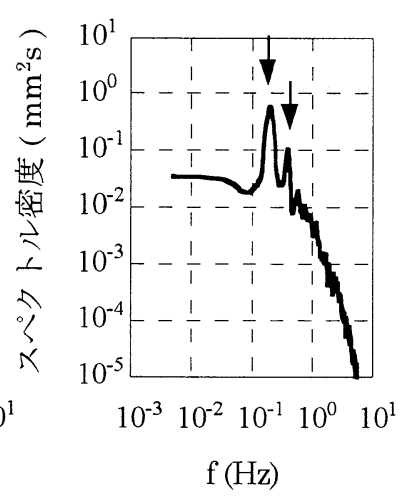

(b) E2
図-7 水面変動のスペクトル分布 $(\mathrm{x}=22 \mathrm{~cm}, \mathrm{y}=40 \mathrm{~cm})$

表-2 水制区間 1 におけるレイノルズ応力最大值 及びその值を示拉位置

\begin{tabular}{|c|c|c|c|c|}
\hline case & $\mathrm{x}(\mathrm{cm})$ & $\mathrm{x} / \mathrm{d}$ & $\mathrm{y}(\mathrm{cm})$ & $-\overline{u^{\prime} v^{\prime}}\left(\mathrm{cm}^{2} / \mathrm{s}^{2}\right)$ \\
\hline E1 & 30 & 1 & 40 & 20.24 \\
\hline E2 & 60 & 1 & 40 & 11.31 \\
\hline E3 & 20 & 0.2 & 40 & 8.51 \\
\hline E4 & 45 & 0.3 & 45 & 14.33 \\
\hline E5 & 80 & 0.4 & 50 & 11.84 \\
\hline
\end{tabular}

一致しているために変動の周期性が強められている。 剥離渦の発達等による乱れの変化を見るために, 水 制区間 1 におけるレイノルズ応力の最大值を比較する

(表-2)．水制間隔の狭いケース E1,E2 では下流側の 水制域からの逆流によって下流側の水制先端付近で最 大值をもっている．水制間隔の広いケース E3,E4,E5 では剥離渦の発達によって水制区間半ばで最大值をも っているが，ケース E3 ではその值が小さい。このこ とは，ケース E3 では剥離渦の発達が抑えられている ことを示している.

\section{4. 水制・主流域間の質量・運動量交換}

\section{（1）境界面における横断方向流速}

流速分布の傾向を見るためにケース E4 の境界面上 での横断方向流速の水深变化を図-8に示守.

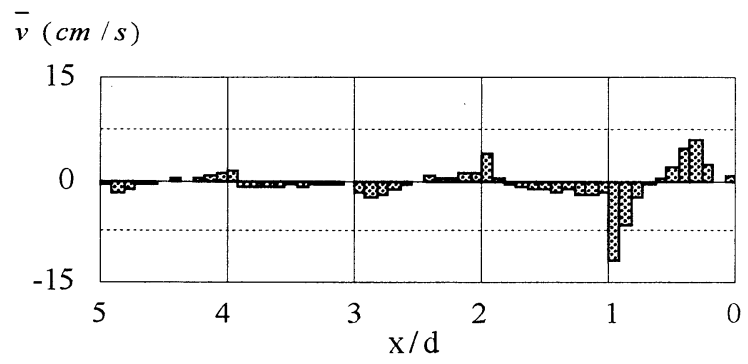
$\bar{v}(\mathrm{~cm} / \mathrm{s})$
(a) $\mathrm{Z}=4 \mathrm{~cm}$

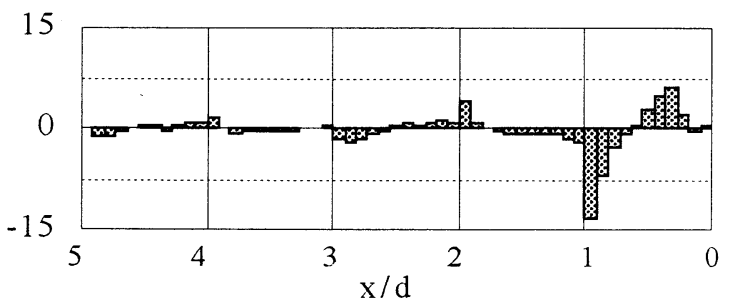

$\bar{v}(\mathrm{~cm} / \mathrm{s}) \quad$ (b) $\mathrm{Z}=3 \mathrm{~cm}$

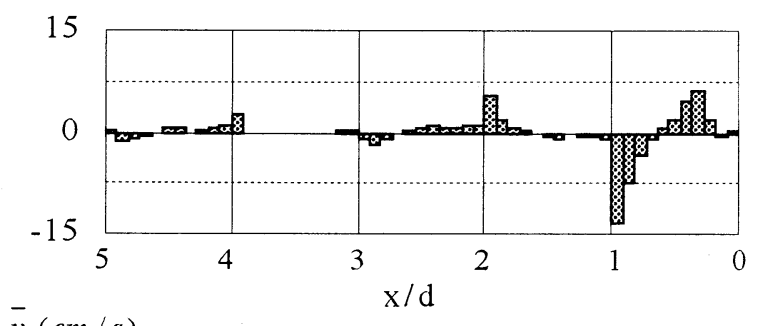

$\bar{v}(\mathrm{~cm} / \mathrm{s}) \quad$ (c) $\mathrm{z}=2 \mathrm{~cm}$

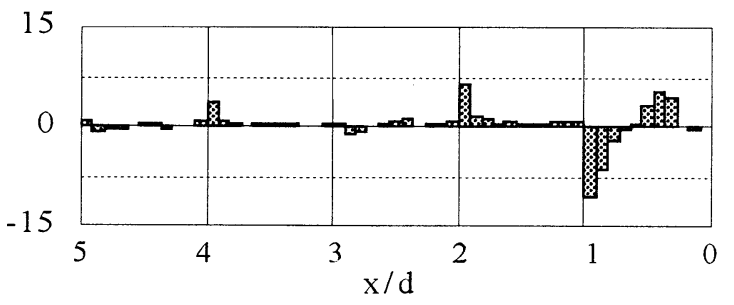

(d) $\mathrm{z}=1 \mathrm{~cm}$

図-8 境界面上の横断方向流速（ケースE4） 
水制区間 1 における横断方向流速が著しく大きく, 単 一不透過水制背後の流れにおいて, 剥離した流れが水 制背後に回り込むことによる遠心力に起因する二次流 によって, 水面付近で流出, 河床付近で流入が起こる 事を指摘している.ケース $\mathrm{E} 4$ では，水制区間 2 から 水制区間 4 までの区間では水深の浅いところで水制域 一の流入が, 深いところで主流域への流出が起こる傾 向にあり，ここで弾一水制周りの流れとは逆になっ ている．このような 3 次元性は，水制間隔が広くなる ほど強くなる傾向が見られた。

\section{（2）質量・運動量交換率の定義}

水制域・主流域間の物質交換を示守指標として，水 制群先端を結ぶラインを境界面とし，この面における 質量交換率，移流と乱れ双方を含む運動量の交換率に 注目した. ある水制区間における境界面での水深平均 した質量交換の絶対值及び，境界面での運動量交換率 を，木村ら ”， 陳・池田 (の)論文を参考にして，断面 平均流速 $\mathrm{U}$, 平均水深 $\mathrm{h}$ 及び水制間隔 $\mathrm{d}$ て無次元化し た值を用いて次のように表す。

$$
\begin{aligned}
& k^{\prime}=\frac{1}{\rho U d h} \int_{0}^{d} \int_{0}^{h} \rho \overline{|v|} d z d x \\
& \theta=\frac{1}{\rho U^{2} d h} \int_{0}^{d} \int_{0}^{h} \rho \overline{u v} d z d x
\end{aligned}
$$

ここに, $\mathrm{k}^{\prime}$ : 無次元質量交換率, $\theta$ : 無次元運動量 交換率である. なお，運動量交換は水制域から主流域 一向かう輸送を正としている。

\section{（3）質量交換}

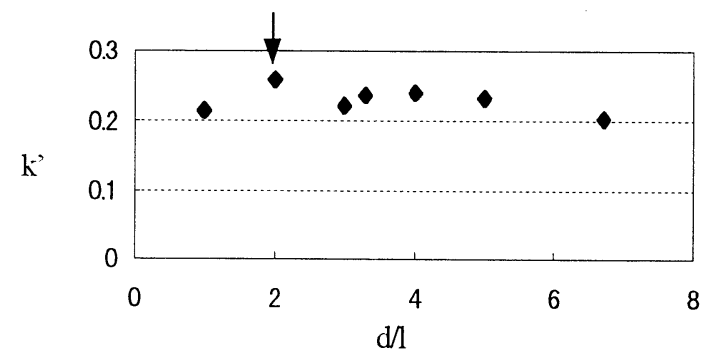

図-9 水制区間 1 の質量交換率

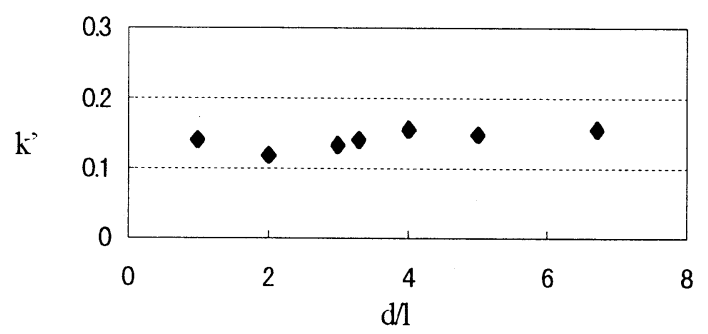

図-10 再付着点より下流側の水制区間における 質量交換率平均值
質量交換率の流下方向一の変化は，横断方向流速と 同じように水制群先頭の水制区間で大きく，下流側の 水制区間では小さい，剥離域に含まれる水制区間は大 きな值をもっており, 水制区間 1 での質量交換率で比 較すると図-9 のようにケース $\mathrm{E} 2(\mathrm{~d} / \mathrm{1}=2.0)$ でピークを もつ. これは，3.（2）a）でふれた水制域内の水面 変動による質量交換が大きいことによると考えられる. また，再付着点より下流側の水制区間での質量交換率 の平均値は，水制間隔の広いケースになるほど大きな 值を持つ傾向にある.

\section{（4）運動量交換}

水制区間 1 における運動量交換率は図-11 のように なる. 水制間融が狭いと正，広くなると負の運動量交 換率となっており, 正の運動量交換率は, ケース E6 (d/1=3.0)でピークをもっている. 再付着点より下 流側の水制区間での交換率の平均值は図-12 の様に全 てのケースで負となっており，また，水制間隔が広く なるほど，大きな負の值を持つ傾向にある.

運動量交換率の流下方向一の変化を図-13 に示す. 水制区間 1 における運動量交換率の流下方向一の分 布は，水制間隔によって大きく異なっている. ケース $E 1(d / 1=1.0), E 2(d / 1=2.0)$ では水制区間前半で負, 後半で正といら分布を持つ. ケース $E 6(d / 1=3.0)$, E3 (d/1=3.3)，E7(d/1=4.0) では水制区間前半で正, 後半で負の值を持つ傾向にあり, 水制 2 付近で極めて 大きな正の運動量交換率を持っている. ケース $\mathrm{E} 4(\mathrm{~d} / \mathrm{l}=5.0), \mathrm{E} 5(\mathrm{~d} / \mathrm{l}=6.7)$ では負の運動量交換が強く なり，水制 2 付近の正の交換は見られない.また，こ の 2 ケースでは水制区間 2 後方の水制 3 付近において 正の運動量交換率が見られる. 水制区間 1 で汒, 後方

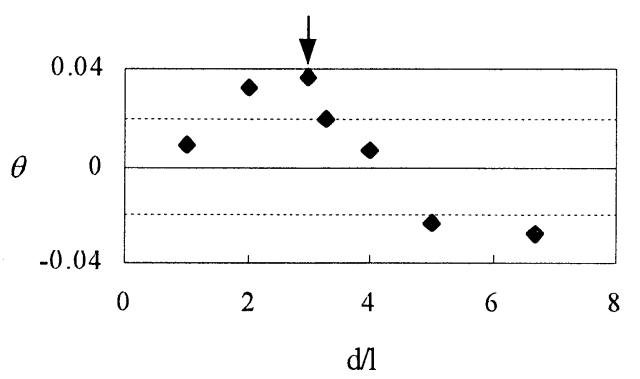

図-11 水制区間 1 における運動量交換率

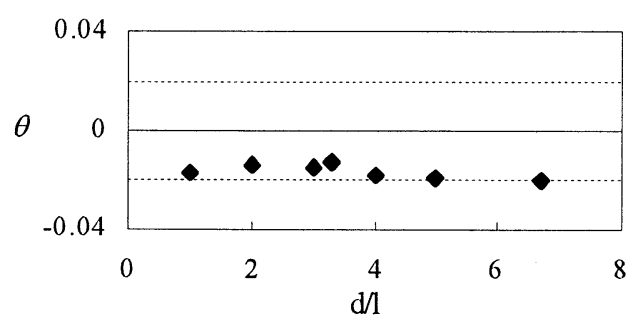

図-12 再付着点より下流側の水制区間における 運動量交換率平均值 

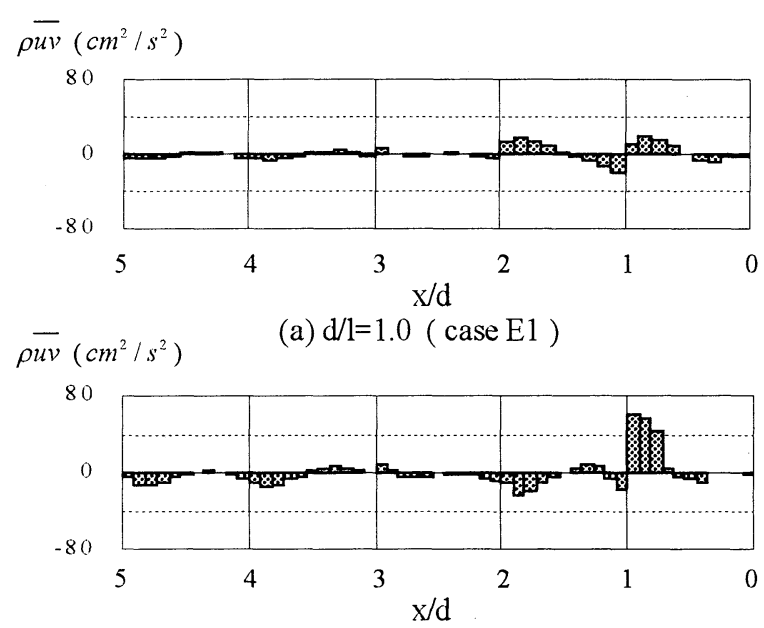

$\rho \overline{u v}\left(\mathrm{~cm}^{2} / \mathrm{s}^{2}\right) \quad$ (b) $\mathrm{d} / \mathrm{l}=2.0($ case $\mathrm{E} 2)$

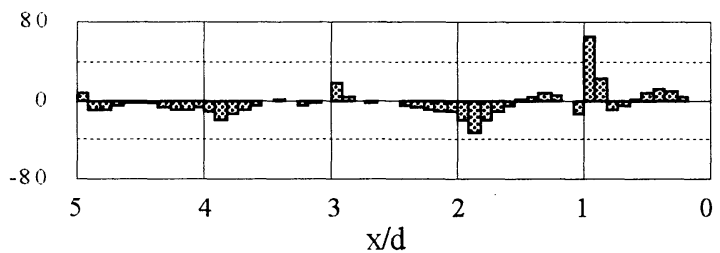

$\rho \overline{u v}\left(\mathrm{~cm}^{2} / \mathrm{s}^{2}\right) \quad$ (c) $\mathrm{d} / \mathrm{l}=3.0($ case E6 )

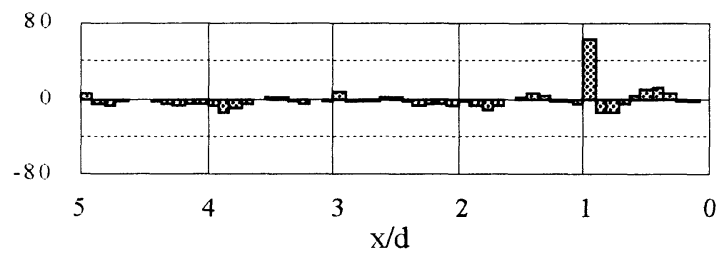

$\rho \overline{u v}\left(\mathrm{~cm}^{2} / \mathrm{s}^{2}\right) \quad$ (d) $\mathrm{d} / \mathrm{l}=3.3($ case E3 $)$

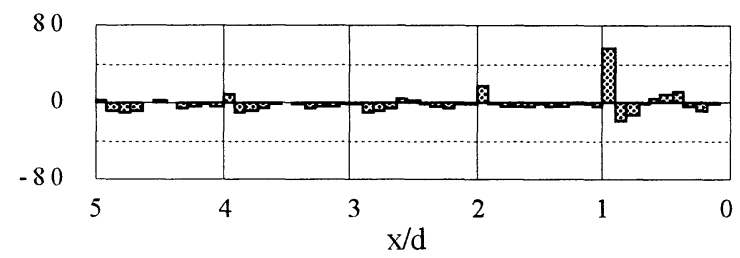

$\rho \overline{u v}\left(\mathrm{~cm}^{\prime} / \mathrm{s}^{\prime}\right) \quad$ (e) $\mathrm{d} / \mathrm{l}=4.0($ case E7)

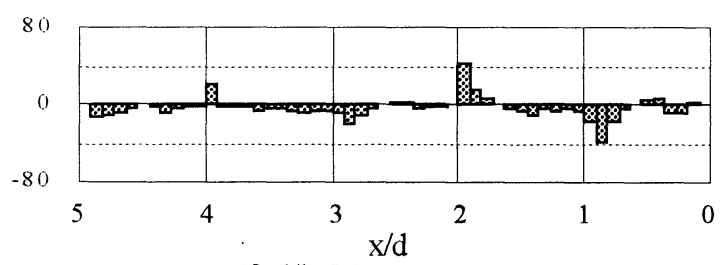

$\rho \overline{u v}\left(\mathrm{~cm}^{2} / \mathrm{s}^{2}\right) \quad$ (f) $\mathrm{d} / \mathrm{l}=5.0($ case E4 )

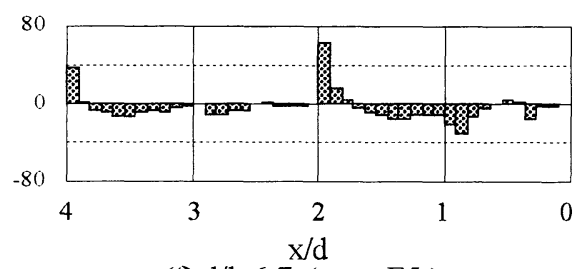

(f) $\mathrm{d} / \mathrm{l}=6.7($ case E5 )

図-13 $\mathrm{z}=2 \mathrm{~cm}$ における境界面上の運動量交換率 の流下方向変化
の水制である水制 2 付近で生じる運動量交換率が大き く，運動量交換の収支はここにおける值に支配されて いる.

\section{4. まとめ}

不透過水制群を有する流れの構造を支配する因子と して水制間隔に注目して実験を行い，以下の結果を得 た.

（1）水制群先頭の水制から剥離した流れは水制間隔 が狭いほど，短い流下距離で再付着する，また，水制 間隔が狭いケース（d/1=1.0, d/1=2.0）においては, 剥離域内の水制区間において，水制先端を前方水制域 八周り込む逆流と水制域での水面の振動が見られた。

（2）水制・主流域間の質量交換率は，水制群の先頭 の水制区間では $\mathrm{d} / 1=2.0$ のケースで最大となる. 再付 着点よりも下流側の水制区間における平均値は水制間 隔の広いものほど大きな值を持つ傾向にある.

(3) 運動量交換率は，再付着点より下流側の水制区 間においては負の交換率を持つ. 水制群の先頭の水制 区間においては水制間隔の狭いケース $(\mathrm{d} / 1=4.0$ 以下 のケース）では正の，広いケース $(\mathrm{d} / 1=5.0, \mathrm{~d} / 1=6.7)$ では負の運動量交換率を持っており，それを支配して いるのは 2 番目の水制先端付近で生じている運動量交 換である.

謝辞 : 本研究は文部省科学研究費基盤研究 (A) (1) (代 表研究者: 池田駿介, 課題番号: 07455195)の補助を 受けたものである. 記して謝意を示します.

\section{参考文献}

1）宗田徳彦 : Reynolds 応力を考慮した水制を含む流れの計 算, 水工学論文集, 第 37 巻, pp. 487-494， 1993.

2）福岡捷二・西村達也・岡信昌利・川口広司: 越流型水制 周辺の流れと河床変動, 水工学論文集, 第 42 巻, pp. 977 -1002, 1998.

3）大本照憲・平川隆一 : 越流型水制群に対寸る二次流と流 砂の応答，水工学論文集，第 42 巻，pp. 1003-1008，1998. 4）松岡保正 : 大規模水制群内の水平渦，水工学論文集，第 39 巻, pp. 773-778, 1995.

5）陳 飛勇・池田駿介 : 水制周りの水平剥離渦に関する実 験的研究, 水工学論文集, 第 40 巻, pp. 787-792, 1994.

6）藤田一郎：トレーサを利用した実河川水制周辺流れのビ デオ画像解析, 水工学論文集, 第 42 巻, pp. 505-510, 1998. 7) 木村一郎・細田尚ほか: 開水路流れにおける死水域内流 体振動に及ぼす水理パラメーターの効果, 水工学論文集, 第 39 巻, pp. 779-784, 1995.

（1998. 9. 30 受付） 